\title{
Between system maker and privileges taker: the role of China in the Greater Mekong Sub-region
}

\author{
Entre criador do sistema e aproveitador de privilégios: \\ o papel da China na Sub-região do Grande Mekong
}

http://dx.doi.org/10.1590/0034-7329201400210

TRUONG-MINH VU*

Rev. Bras. Polit. Int. 57 (special edition): 157-173 [2014]

\section{Introduction}

The rise of China not only changes the power structure of the world, but also becomes one of the phenomena affecting global development in the $21^{\text {st }}$ century in terms of economics, society, politics and strategy. Apart from statistics and indicators of economic development, foreign investment, military spending and activities to disseminate soft power made in China, the question that attracts a great deal of interest of researchers and political observers is about transformation of the Chinese power into political influence, as well as foundation of a new order centered China as a leader. While some argue about a "Chinese exceptionalism" breaking all the rules forecasted in international relations ${ }^{1}$, some explain, based on Chinese norms and values, the attractiveness of its culture and society to hypothesize a China "bound to lead" which is similar to the role of "international leadership" used to associating with the USA in the $20^{\text {th }}$ century ${ }^{2}$. Contrary to the positive picture, there are opposite arguments about a collapsing China, a Chinese threat or a Chinese hegemony aiming only to power and power strengthening ${ }^{3}$.

\footnotetext{
* Faculty of International Relations, College of Social Sciences and Humanities, Vietnam National University, Ho-Chi-Minh City, Vietnam (truongminhhuyvu@gmail.com).

1 Feng Zhang, "The rise of Chinese exceptionalism in international relations," European Journal of International Relations, Vol. 19, No. 2 (June 2013), 305-328; Benjamin Ho Tze Ern, The Rising Chorus of Chinese Exceptionalism, RSIS Working Paper (April 2013), No. 256.

2 Zhang Weiwei, The Chinese Wave: Rise of a Civilizational State, World Century Publishing Corporation (March 2012); Martin Jacques, When China Rules The World: The End of the Western World and the Birth of a New Global Order, Penguin; 2. edition (March 2012).

3 Gordan Chang, The Coming Collapse of China, Random House (July 31, 2001); John Mearsheimer, "The Gathering Storm: China's Challenge to US Power in Asia," The Chinese Journal of International Politics, Vol. 3, No. 4 (Winter 2010), 381-396; Cheng Li, "The End of the CCP's Resilient Authoritarianism? A Tripartite Assessment of Shifting Power in China," The China Quarterly, No. 211 (September 2012), pp. 595-623.
} 
The different, or even opposite, views stem from the fact that potential impact of Chinese leadership is that it is multifaceted, regarding both its inner force and its performance. This depends on power, the way to utilize power and interactions between China on other countries on a specific issue.

Utilizing China's leadership projects in the Great Mekong Sub-Region (GMS) as a case study, this paper aims to investigate how China strives to exercise power and whether China qualifies as an international leader. "Leadership project" in this article is understood as Chinese efforts to establish a regional order in various fields which enables it to have close interaction with the neighboring countries. We focus on China's role in GMS partly because of its strategic importance. China's increasing presence from economy to military links to a potential emergence of Chinese influence spheres, where Mainland Southeast Asia is regarded as China's "backyard." For many observers, China's regional leadership constitutes an irresistible outcome of China's remarkable economic performances and influences 4 . In addition, Mainland Southeast Asia includes countries belonging to "Chinese tribute systems" in the past. Fairbank's well-known concept "Chinese world order" provides a model to understand the international relations in Asia, which constructs China as role of centrality and superiority in this system ${ }^{5}$. Those who put emphasis on the long history of hierarchical order in Asia tend to endorse the fact that the Middle Kingdom returns to the center as the most dominant power and regional leadership, no longer a contested claim ${ }^{6}$.

This paper argues that its geographic position and economic rise allow China to be a "system maker and privilege taker" , which is a dual role forming in economic-political relations in the GMS in the last ten years. China is among major driving forces to set up an economic zone in GMS. Based on empirical findings, we argue that a new regional order has been shaping under the China's leading role. Growing Chinese regional power is intimately related to the creation of various hubs connecting regional transportation, communication and energy systems that foster the economic development of this region. Despite political

4 James Masterson, "Analysing China’s economic interdependence and political relations with its neighbours," China Information 26 (March 2012), pp. 3-33; Xiangming Chen and Curtis Stone, "China and Southeast Asia: Unbalanced Development in the Greater Mekong Subregion," European Financial Review, August 20, 2013; Ravindran Madhu Sudan, "China's Potential for Economic Coercion in the South China Sea Disputes: A Comparative Study of the Philippines and Vietnam," Journal of Current Southeast Asian Affairs, 31, 3, pp. 105-132; Samphantharak Krislert, "The Rise of China and Foreign Direct Investment from Southeast Asia," Journal of Current Southeast Asian Affairs, 30, 2, pp. 65-75.

5 John Fairbank, The Chinese World Order; Traditional China's Foreign Relations, Cambridge, MA: Harvard University Press (1968).

6 David Kang, China Rising: Peace, Power, and Order in East Asia, Columbia University Press (November 2007), "Authority and Legitimacy in International Relations: Evidence from Korean and Japanese Relations in Pre-Modern East Asia," The Chinese Journal of International Politics, Vol. 5, Issue 1 (Spring 2012), pp. 55-71; Brantly Womack, "Asymmetry and China's Tributary System," The Chinese Journal of International Politics, Vol. 5, No. 1 (Spring 2012), pp. 37-54.

7 Michael Mastanduno, "System Maker and Privilege Taker: US Power and the International Political Economy," World Politics 61, No. 1 (2009), pp. 121-154. 
ongoing tensions, large transport infrastructure projects have been realized such as the North-South Economic Corridor (NSEC), the East-West Economic Corridor (EWEC), and the Southern Economic Corridor (SEC) all of which the initial focus was to reduce the sheer physical obstacles for communication, investment, and trade. In addition, China's promotion of hydropower has contributed to ensure the region's energy supply. As China does not only support budgets and offers techniques to construct hydropower plants in Myanmar, Lao PDR and Cambodia, but also promotes electricity exchanges with Vietnam and Thailand, the country is coming close to forming the center of a sort of technological "hub-and-spoke" system in the GMS's electricity field.

However, China also proves dark sides of rising powers which take advantage of their privileges to gain benefits. Evidence from developing projects of hydropower along Mekong River demonstrates that China has qualified the status of "system maker and privilege taker" in both following meanings. First, thanks to a favorable position (and thanks to the country's rich power resources—compared to other GMS countries), Chinese policies have great impacts on the entire River, especially on lower river states. China not only locates at the highest point in the upstream, but also covers a large area of the Mekong River Basin (holding for $165,000 \mathrm{~km}^{2}$ area), hence can control most of the water flow. As a "system maker" with its own position and capability, China has notably benefited from building hydropower systems. Second, they are also indicators that prove China as a privilege taker in negative-sense: While China is pursuing its benefits and privileges, its hydropower projects have caused some negative effects for the ecosystem in the region. Countries like Cambodia or Vietnam have suffered environmental and economic consequences from the boom of hydropower plants on Mekong River, which has currently become a security threat.

We proceed as follows. The following part will briefly introduce the GMS and some major problems that the GMS' countries are now facing. Based on this, the fourth and fifth parts will analyze the role of China in two specific leadership projects: developing infrastructure and developing hydropower projects. The conclusion will review all empirical findings which enable us to have more detailed assessments on the Chinese role in an expanded South East Asia's context within theoretical arguments about the rise of China and its role in a new forming order of the world politics. Our concluding part addresses the pressing need to start a serious discussion on the balance between national interests and regional solidarity within the formulation of Chinese foreign policy in GMS.

\section{Background: the Greater Mekong sub-region}

The Greater Mekong Sub-region (GMS) occupies approximately 2.3 million square kilometer $\left(\mathrm{km}^{2}\right)$ and has a population of around 245 million. This area is recognized not only as a physical region but also as a cultural hub containing six 
countries (China, Myanmar, Lao PDR, Thailand, Cambodia, and Vietnam). They share geographical features, as well as similar culture and traditional customs (due to their livelihood along the Lancang-Mekong River) ${ }^{8}$. Having been operated from 1992 sponsored by the Asian Development Bank (ADB), the GMS program is an initiative aiming to promote the development of the Mekong River Basin by fostering regional and market integration of six countries including China (Yunnan Province), Myanmar, Lao PDR, Thailand, Cambodia and Vietnam. Heading to establish a neoliberal market-based economy, the GMS program consists of three strategic focuses called "Three C's": Connectivity, Competitiveness and Community. The GMS has conducted projects in the fields of transport (road and shipping), telecommunication, energy grids, environment, tourism, trade and investment?

Development in the GMS, however, poses a significant challenge in balancing needs and interests of different countries, not only ones inside the region but also the outsiders. In spite of sharing the Lancang-Mekong River with the total length of $800,000 \mathrm{~km}^{2}$, the six countries possess different locations and development levels. Another important actor, China as the most upstream state owing nearly half of the rivers length is also interested in the development of the GMS due to two practical reasons ${ }^{10}$. The first one is to establish a stable foundation for developing its southwestern provinces such as Yunnan. Connecting transportation, investment and trade with the Southeast Asian neighbors will create a strong boost for economic development for this region. The initial focus of the transport infrastructure projects is to reduce physical obstacles for investment and trade. Some development projects have been conducted such as the North-South Economic Corridor (NSEC), the East-West Economic Corridor (EWEC), and the Southern Economic Corridor (SEC). The second reason is to utilize the Mekong River to promote hydropower, seeking not only to provide electricity for the Yunnan Province and the eastern provinces of China but also export electricity and hydropower facilities to the SEA countries.

Besides China, two other upstream states of Lao PDR and Myanmar also show their interests in developing river-dependent economies. However, due to their low development level (that is, Myanmar was politically isolated for a long time and Lao PDR is among the poorest countries in SEA and in the world), the two countries lack capabilities and resources to implement development projects. They have mostly depended on cooperation with neighboring countries such as China

8 Jörn Dosch, "Managing security in ASEAN-China relations - liberal peace of hegemonic stability", Asian Perspective, Vol. 31, No. 1 (Spring 2007), pp. 224.

9 ADB, "Greater Mekong Subregion" Retrieved from http://www.adb.org/GMS/, 17 June 2013, accessed 23 June 2013.

10 Susanne Schmeier, "Regional Cooperation Efforts in the Mekong River Basin: Mitigating river-related security threats and promoting regional development," Austrian Journal of Southeast Asian Studies, No. 2 (2/2009), pp. 32-33. 
or Thailand to build their hydropower. Meanwhile, the three downstream states of Thailand, Cambodia and Vietnam have pursued diverse benefits in development of the GMS. The Thai government desires to export electricity which is expected to be produced by more hydropower plants, and fosters regional integration to create new markets and new investment opportunities. At the same time, Cambodia and Vietnam as economies heavily reliant on agriculture and agricultural exports have been attempting to harmonize the economic development with the vulnerability caused by changing the Mekong flow regimes or other related negative impacts. In the context of the global climate change, both of the two countries are said to be serious victims of natural disasters, which particularly derive from environmental changes of the Lancang-Mekong River ${ }^{11}$.

The above introduction shows that the development of the GMS is a complex puzzle approached by diverse perspectives. Being named "development projects," projects of transportation, infrastructure, and hydropower constructions have their great contribution to developing economies and poverty alleviation of countries in the region. However, the acceleration of regional cooperation, especially in hydropower field, will negatively impact the environment and hurt the downstream states both environmentally and economically. Water management within this global climate change, therefore, is a great challenge. In this context, China appears as a leader bringing various development projects which are expected to solve those problems in order to bring the common prosperity to the region. The following case studies will particularly focus on two Chinese leadership projects contributing to the development in the GMS, namely the infrastructure development project and the hydropower development project.

\section{China's leadership projects: infrastructure developments}

The Chinese leadership projects in terms of infrastructure development are assumed to start when the Chinese Prime Ministers often attended the GMS Summits from 2002 to 2005 offering initiatives to promote regional cooperation. The statement of the Chinese Prime Minister Zhu Rongji at the fourth Informal ASEAN Summit in Singapore, for instance, emphasized financial support from China to develop the infrastructure system in the region, specifically promoting the Kunming-Bangkok Highway facilitation of transport. On 31 March 2008, the successor of Zhu, the Prime Minister Wen Jiabao attended the third GMS Summit in Vientiane, Lao PDR and delivered an important keynote speech focusing on infrastructure of transport "the GMS should step up the building of transport corridors and a highway network linking all members of the sub-region. China is ready to work closely with Thailand and the Asian Development Bank (ADB)

11 Carl Middleton, "The Sleeping Dragon Awakes", Watershed Journal, Vol. 12, No. 3 (November 2008), pp. $51-64$. 
to expedite the building of the Houayxay-Chiang Khong International Bridge along the Kunming Bangkok Highway with the aim to link all the sections of the North-South corridor by 2011 "12.

The two most important projects are the North-South Corridor and the attempt to construct a railway network for the whole GMS. The North-South Corridor also places at the center of the China's participation in the GMS program. This corridor stretches from the southern Chinese city of Kunming in Yunnan Province to Bangkok including the populated Luang Namtha province in northern Lao PDR, the Shane state in western Myanmar, and the northern Thai cities of Chiang Rai, Chiang Mai and Phitsanulok. The North-South Corridor also includes the area from the southeast of Kunming to Hanoi ${ }^{13}$. At the same time, the attempt to construct a railway network aims to improve the railway systems of the GMS countries built in the colonial period two centuries ago. Most of them are limited inside the country's borders and just some of them are linked with one of their neighbors.

Besides, the China's ambition to connect all the GMS countries (and SEA countries in a wider scale) by the railway network seeks to serve for two main purposes. The first one is to establish a transport system supporting trade between countries and facilitating the Chinese development policy in its Southern provinces. Regarding this purpose, the Economist comments "Most countries along the route have already hitched their wagons to China's outsized economy and are eager for more trade" 14 . The second one can be seen as an access of China to the Indian Ocean, based on examining the connecting points of the railway system offered by China (such as the road connecting Yannan and Myanmar). This is assumed as an approach to a new market and as a strategy ensuring the transits of the Chinese energy to the world ${ }^{15}$.

The role of China as "system maker" in the GMS its manifested in its contribution to both the public goods for the regional integration and private goods for member countries. In 2005, the Chinese government announced to contribute US\$ 20 million to establish a technical assistance fund run by ADB. Within the attempt to build a fund for economic development of mainland SEA, China (associates with ADB) set up a China-ASEAN Fund on Investment Cooperation valued US\$ 10 billion to support regional infrastructure development ${ }^{16}$.

12 "Chinese premier makes proposals on boosting co-op in GMS", Xinhuanet, March 31, 2008, http://news. xinhuanet.com/english/2008-03/31/content_7890305.htm, accessed 29 June 2013.

13 Lim Tin Seng, "China's Active Role in the Greater Mekong Sub-region: Challenge to construct a "win-win" relationship," East Asian Policy, Vol. 1 (Jan/Mar 2009), pp. 40.

14 "China coming down the tracks", The Economist, http://www.economist.com/node/17965601, accessed 23 June 2013.

15 Anthony Kuhn, "Full Steam Ahead For China's Rail Links Abroad?”, NPR, June 14, 2011, http://www.npr. org/2011/06/14/137111321/full-steam-ahead-for-chinas-rail-links-abroad, accessed 23 June 2013.

16 Geoff Wade, “Could ASEAN Drift Apart?” Yale Global, February 25, 2011, <http://yaleglobal.yale.edu/ content/could-asean-drift-apart>, accessed 29 June 2013. 
Furthermore, a railway network will connect all the GMS countries in 2020 which China plays the role of the crucial sponsor. In particular, China funded the projects of high-speed railways and roads connecting Kunming and Yangon, Bangkok, Vientiane and Phnom Penh, besides an electricity network and energy pipelines passing those countries to mainland China. Within the bilateral mechanisms, China also seems to create great benefits for GMS countries.

China is not only a huge investor in Myanmar, Cambodia and Lao PDR but also the most important aid provider for these countries. According to Xinhua News Agency, China invested US\$ 5.7 billion, which counts for over 20\% the total FDI of Cambodia from 1994 to 2008. In return, what China gets in Cambodia includes benefits from mining, forestry, oil, civil engineering and biofuel. In addition, Chinese companies are major investors in the new special economic zone of Koh Kong near the southern port of Sihanoukville ${ }^{17}$. According to the Cambodia Investment Board, the investment indicators seem to grow in the recent years, especially in the field of infrastructure. The figure has reached US\$ 9.1 billion since 1994, including almost US\$ 1.2 billion in 2011—eight times more than the US (Cambodia Investment Board). The similar increase can be found in the China's aid packages to Cambodia. Within the GMS framework, a concessional loan for building the super highway was provided by the Chinese government to Cambodia ${ }^{18}$. Most recently, during Cambodian Prime Minister Hun Sen's five-day visit to Beijing, the two sides concluded a bilateral agreement in which China promised to provide another US\$ 548 million in aids to Cambodia for infrastructure and irrigation systems, and help build $400 \mathrm{~km}$ (250 miles) of new roads a year over several years ${ }^{19}$.

A similar situation also happens in Lao PDR, when this country's economic growth mostly depends on the cooperation with other bigger neighbor countries among which China is the most important. Some aid projects to build infrastructure in Lao PDR granted by China have been noted. For instance, China provided US\$ 30 million as non-refundable aids for the Laotian government to build an $85-\mathrm{km}$ highway, which is one part of the Kunming-Bangkok highway. In a visit to Lao PDR in 2008, the Chinese Prime Minister Wen Jiabao promised to distribute US\$ 100 million to develop public projects including telecommunication, transportation and transmission line ${ }^{20}$.

In Myanmar, China is now a source of development aid, as well as the greatest investor during the period the country was imposed sanctions by Western

17 Geoff Wade, 2011.

18 Zhu Zhenming, "China's Economic Aid to CLMV and Its Economic Cooperation with Them,", in: Kagami, M. (eds.). A China-Japan Comparison of Economic Relationships with the Mekong River Basin Countries, BRC Research Report: pp. 76.

19 "China pledges US\$ 548 million in aid to ally Cambodia", April 10, 2013, <http://www.reuters.com/ article/2013/04/10/cambodia-china-idUSL3N0CXDAC20130410>, accessed 29 June 2013.

20 Zhu Zhenming 2008, pp. 78. 
countries. The Chinese support consists of transportation, infrastructure (roads and bridges), agriculture, communications, education and training, sport, stadium, etc. The calculation of the CRS reports $(2009,17)$ shows that the total investment of China to Myanmar during 2002 to 2007 reaches US\$ 3.1 billion $^{21}$. When Than Shwe, the leader of the Burmese military government, visited Beijing in January 2013, China promised to the Burmese government a preferential loan of US\$ 200 million and a non-refundable aid of US\$ 6.25 million $^{22}$. The Burmese government states that the Chinese government has provided about 2.15 billion yuan and US\$ 400 million in forms of credit $^{23}$.

China is also an important partner of Vietnam in terms of investment and aid grants. According to $\mathrm{Ha}$ and Do, until 2007 there had been 628 investment projects of China approved in Vietnam with the total value of US\$ 2,198 million $^{24}$. According to Asia Times, China provided a package of development aid to Vietnam valued US\$ 312 million from 1997 to 2004, including US\$ 50 million of non-refundable aid ${ }^{25}$. In a research named "China's economic aid to Cambodia, Lao PDR, Myanmar and Vietnam," Zhu Zhenming proved that around US\$ 307 million was handed to Vietnam under various projects of agriculture and infrastructure during the period of 2002 and $2008^{26}$. However, the authors Lum/Fischer/Gomez-Granger/Leland argue that the total amount of financial aid and investment of China to Vietnam from 2002 to 2007 is much greater, reaching US\$3.4 billion, a large portion of which came to projects of infrastructure, shipbuilding and mining ${ }^{27}$. If they provide correct information, then China is among the biggest aid donors of Vietnam, in terms of number of aid projects and loans within the bilateral cooperation (compared to Japan and other Western donors).

The Chinese approach through the GMS mechanism has brought this country an impressive success which is described by international observers as a "charm offensive" or "Chinese soft power." The role of China as the largest donor in developing the infrastructure in GMS has often been considered to be a vital component of building a new regional structure. About this, Jörn Dosch states

21 Lum, T., Fischer, H., Gomez-Granger, J. and Leland, A., China's Foreign Aid Activities in Africa, Latin America, and Southeast Asia, CRS Report for Congress (R40361).

22 Toshihiro Kundo, "Myanmar's economic relations with China: who benefits and who pays?", in: Skidmore, M.; Wilson, Tr. (eds.). Dictatorship, Disorder and Decline in Myanmar, ANU E Press, pp. 97.

23 Toshihiro Kundo, "Myanmar's economic relations with China: who benefits and who pays?", in: Skidmore, M.; Wilson, Tr. (eds.). Dictatorship, Disorder and Decline in Myanmar, ANU E Press, pp. 97.

24 Ha Van and Do Sam, "Vietnam-China Trade, FDI and ODA Relations (1998-2008) and the impacts upon Vietnam”, in: Kagami, M. (eds.). A China-Japan Comparison of Economic Relationships with the Mekong River Basin Countries, BRC Research Report, pp. 278.

25 "China, Vietnam find love“, Asia Times, June 21, 2005, <http://www.atimes.com/atimes/Southeast_Asia/ GG21Ae01.html>, accessed 17 June 2013.

26 Zhu Zhenming 2008, pp. 81-82.

27 Lum, T., Fischer, H., Gomez-Granger, J. and Leland, A., 2009, pp. 17. 
in his work that "China has started to act like a traditional big power, proactively drawing up its own blueprints for regional order and pulling smaller neighbors along in its wake. Most ASEAN states have responded positively to this strategy by jumping on the Chinese bandwagon, as both the examples of security management in the South China Sea and the Mekong valley have shown"28. Until now, this strategy has proved its effectiveness as it stamps out the fear of a "China threat" of the GMS countries. The Chinese favorable outcome of persuading GMS neighboring countries to join its leadership project within the GMS framework has helped improve the China's position in two major aspects.

- First, by successfully conducting this leadership project (in developing regional infrastructure), China has gradually balanced with Japan in terms of influence in the SEA, which is the first achievement of China thanks to this project. A common market in the south (of China and Japan) can only be completed and developed based on a transport system which closely connects neighboring regions. However, building a trans-Asian transport network is not only a concern of investment or trade but also a competition of regional powers with regard to political influence. Although there have been no explicit indicators or proof showing the impact of the two Asian powers of China and Japan on the SEA issues, it is obvious that China has appeared in this zone as a crucial actor. This proves that not only Japan, the US or the EU can bring a win-win situation and a common prosperity for this region, but China can also do the same and even do it well.

- Second, the Beijing government by this success can transfer its power resources into institutionalized power semiofficially with the establishment of a pan-Asian railway network. It can be foreseen that once the railway comes into real life (particularly with the South-North Economic Corridor), China will, thanks to its advantage of location and population, become an important hub connecting the whole mainland area of the SEA. Compared to other countries in the region, China seems to be more successful in promoting cross-border networks of GMS by constructing roads and railways. Commenting on the Chinese approach, an encapsulating idea states that this approach "enabled international organizations to move ahead with their pan-Asian agendas, while these bodies in turn allowed the Chinese government to develop cross-border linkages without straining its financial resources or raising any suspicions of a new kind of mercantilist railway diplomacy ${ }^{29}$. Especially, it should be emphasized that a trend of transferring "authority" to China (or "power" in terms of influence

28 Jörn Dosch, "The Fallacy of Multilateralism Rhetoric in China-Southeast Asia Relations - A Neo-Realist Perspective on Regional Orderbuilding," UNISCI Discussion Papers, № 24 (October 2010), pp. 135-152.

29 Jonathan Holslag, "China's Roads to Influence, "Asian Survey, Vol. 50, No. 4 (August 2010), pp. 653-654. 
capability) has been done by Japan and Western countries as "providers" of the regional prosperity of the GMS. Competing and cooperating with Japan in various fields has helped China become a driving force, besides Japan, in connecting Mekong regional states aiming to creating an order and solve regional challenges.

\section{China's leadership projects: hydropower developments}

There are two other indicators which prove the Chinese role as a "system maker" in developing hydropower projects in GMS. First, as mentioned above, China is located in the uppermost region of the Mekong River Basin (hold for $165,000 \mathrm{~km}^{2}$ area) and controls most of the Mekong's stream flows. Thanks to the location and economic-military power, China can be seen as a "dominant power with favorable riparian position" as defined by Lowi. China assesses projects of dam construction as an important part in their developing strategy in the Western China. The upstream region occupies half-length of the Lancang-Mekong River, receives water from melting ice of the Tibet plateau shaping waterfalls with huge slope, some are 600 meters high. Along this area, China has built eight dams, four of which came to operation: Manwan Dam (126 m high, finished in 1993); Dachaoshan Dam (118 m, 2003); Jinghong Dam (107 m, 2007) and the greatest one Xiaowan Dam (292 m) which started to take water from the Mekong River into the reservoir $250 \mathrm{~km}$ long. In the middle stream of Mekong River, since 2006, eleven projects of dams were established (seven in Lao PDR, two at the border area of Lao PDR and Thailand, two in Cambodia) creating a series of dam 30-40 meters high. Most of the dams in Lao PDR and Cambodia are built by China. While Thailand has taken a leading position amongst a diverse set of investors in developing Lao PDR's hydropower potential, China has taken a near-monopoly position in developing Cambodia's ${ }^{30}$.

Second, as being stated in the part of background information, most of the GMS countries are developing economies in which exploiting energy, specifically electricity, plays an important role in guaranteeing a high economic growth rate and modernization. Therefore, the fact that mayor Chinese state-oriented enterprises (SOE), which are supported politically by its government and financially by its national banks, involve in the building of electricity generation facilities in Vietnam, Laos, and Myanmar "offers a good example of the emergence of reciprocally beneficial linkages between China and the states in its zone of influence"31. In Myanmar, China plays a major role in financial and technical support to help the Burmese government building hydropower plants in order

30 Phua Peipei, "China's Collaboration with Indochina Countries in Hydropower Development in the Mekong Region: How Far Can It Go?”, in: Li/Guan (eds.). China-Asean sub-regional cooperation: progress, problems and prospect, World Scientific, pp. 95-124.

31 Jörn Dosch, 2010. 
to generate electricity for domestic use. A Chinese company named Sinohydro in 2006 gained a Memorandum of Understanding with Myanmar to build a dam (called Gyi) of 1,200 MW along the Thai border. In April 2007, an energy company of Holding Group and China Gold Water Resources Company signed with the Burmese military government a project of additional 2,400 MW taken from the Salween River. In April 2008, Sinohydro, China Southern Power Grid Co. and China Three Gorges Project Co. signed a framework of cooperation to develop the hydropower potential of the Salween River ${ }^{32}$.

Electricity cooperation between China and Vietnam also bring to this country benefits in developing energy infrastructure. In 2006, China Southern Power Grid Company (CGS) associated with the Electricity of Vietnam (EVN) to develop a hydropower station in Lao Cai with the total value of US\$28 million ${ }^{33}$. In 2009, the Chinese Guangdong Nuclear Power Group announced to help Vietnam build its first nuclear power plant, comprising two 1,000-MW reactors located in the southern coastal province of Ninh Thuan. Since 2004, Vietnam has increasingly imported electricity from two Chinese provinces of Yunnan and Guangxi. In the early 2013, the EVN requested the Vietnam electricity companies to buy electricity from China as much as possible to ensure the security of the domestic electricity consumption, which is expected to reach 380 million $\mathrm{kWh} /$ day $^{34}$. Lao PDR and Cambodia are also on the way of modernization and are in dire need of hydropower development to serve for their industries. The two countries hence have received millions of dollars in aid from China in this field. In particular, the Kamchay Dam (193 MW) in Kampot province was built by the Sinohydro Corporation in 2007, the Stung Atai project (120 MW) was built by China Yunnan Corporation for International Techno-Economic Cooperation ${ }^{35}$.

The Chinese leading project in developing dams, however, has received unclear results from GMS countries, with regard to their support and acceptance. Responses of the GMS countries explain for the dark side of the Chinese hegemony in the region. This demonstrates that China just mainly concentrates on its privileges while fostering its leadership projects without concerning interests of the neighboring countries in GMS. In the record of hydropower development and water management of the Mekong River, research results about the Chinese behaviors show that this country is more about conducting "unilateral" actions. As mentioned above, China is located in the uppermost region of the Mekong

32 "Salween Dams", International Rivers, http://www.internationalrivers.org/campaigns/salween-dams, accessed 17 June 2013.

33 Middleton, 2008.

34 "EVN yêu cầu mua điện tối đa từ Trung Quốc" (EVN maximum power required to purchase from China, available at $<$ http://news.dbv.vn/evn-maximum-power-required-to-purchase-from-china-26442.html $>$ ), Tuoi Tre, May 5, 2013, http://tuoitre.vn/kinh-te/547417/evn-yeu-cau-mua-dien-toi-da-tu-trung-quoc.html, accessed 29 June 2013.

35 Middleton, 2008. 
River Basin (hold for 165,000 $\mathrm{km}^{2}$ area) and controls most of the Mekong's stream flows. Thanks to the location and economic-military power, China can be seen as a "dominant power with favorable riparian position" 36 . The three following indicators figure out that China has tried to take advantage of its power ${ }^{37}$. First, the Chinese hydropower plans in the upstream of the Lancang River are not information-shared or consulted with the downstream countries.

Second, China refused to sign the "Agreement on the Cooperation for Sustainable Development of the Mekong River Basin," which created the Mekong River Commission (MRC) in 1995 including the four riparian countries of Cambodia, Lao PDR, Thailand, and Vietnam. The MRC countries have many times persuaded China to join this group ${ }^{38}$. However, so far China has still not become a member of the MRC. Together with Myanmar, this power just plays the role of a dialogue partner of this group. The lack of the two upstream countries of China and Myanmar is assumed to lead to the weakness of the MRC as an international regime aiming to create an institutional framework to regulate to the use of water resources. Third, the Chinese unilateralism is often mentioned due to its vote against the United Nations on the Law of the Non-Navigational Use of International Watercourses in 1997. This convention emphasized the "equitable and reasonable utilization" of international rivers. Besides 103 countries voted favor and 27 abstentions, China, Turkey and Burunidi voted full objection. Some observers believed that the Lancang River and the Chinese hydropower plans on this flow was the major reason for its objection ${ }^{39}$.

On the other hand, some recent evidence has shown that China "is tending away from unilateralism, and is gradually getting involved in negotiation mechanism and process with the downstream states" ${ }^{30}$. For instance, in April 2002, China signed a cooperative agreement with the MRC to provide information about the river flow and water levels ("the Agreement on the Provision of Hydrological Information of Lancang-Mekong River in Flood Season"). In the fourteenth dialogue between the Mekong downstream countries (Thailand, Laos, Cambodia,

36 Miriam Lowi, Water and Power - The Politics of a Scarce Resource in the Jordan River Basin, (1995) Cambridge, USA: Cambridge University Press.

37 Kayo Onishi, "Interstate negotiation mechanisms for cooperation in the Mekong river basin," Water International, Vol. 32, No. 4 (2007), pp. 52; "Reassessing Water Security in the Mekong: The Chinese Rapprochement with Southeast Asia," Journal of Natural Resources Policy Research, Vol. 3, No. 4 (2013), pp. 393-412.

38 Actually, since 2002, there have been some predictions about the prospects of Chinese participation. In the Joint Committee meeting and the following Dialogue meeting in 2004, the chairman of the Joint Committee and State Secretary under the Thai Ministry for Environment, Siripong Hungspreug, who allegedly announced that it would be "highly possible for China to join us", cited in Timo Menniken, "China's Performance in International Resource Politics: Lessons from the Mekong," Vol. 29, No.1 (April 2007), pp. 109.

39 Timo Menniken, 2007; Evelyn Goh, Developing the Mekong: Regionalism and Regional Security in ChinaSoutheast Asian Relations, Adephi paper No. 387 (London: IISS, June 2007); Alex Liebman, "Trickle-down Hegemony? China's "Peaceful Rise" and Dam Building on the Mekong," Contemporary Southeast Asia, Vol. 27, No. 2 (August 2005), pp. 281-304.

40 Kayo Onishi, 2007, pp. 525; 2013, pp. 397-398. 
Vietnam) and their important partners of China and Myanmar in 2009, China expressed its idea to share more information about the ongoing hydropower plans and its future construction projects in the upstream region. China also announced some solutions it had conducted not to change the flow in the downstream region; as well as committed to join the environmental assessment on scheduled hydropower plants in the downstream Mekong that the MRC was carrying on. Recently, China has agreed to share more information of the "operational data" to the MRC and allowed some of the Committee's officials accompanying Chinese experts of the Strategic Environmental Assessment to visit Xiaowan (4,200 MW) and Jinhong $(1,350 \mathrm{MW})$ among the hydropower dams working in Yunnan Province.

Based on those indicators and the fact that China agreed to take part in the MRC as a dialogue partner, Onishi even argues that it is not fair to assess China as a non-cooperative actor tending to act unilaterally ${ }^{41}$. Although noting this opinion and evidence, we argue that Chinese behaviors in GMS in terms of developing hydropower dams and managing water of the Mekong River cannot be assessed as power sharing, due to two specific reasons. Firstly, China has not restricted its power in a particular institution/ management regime governing the use of trans-boundary rivers or in compliance standards governing hydropower development (except for the Agreement on the hydrological date exchange). The most important factor of the sustainable development in GMS is finding a balance between developing hydropower and environmental impacts; hence it is necessary to build a mechanism regulating the dam constructions and hydropower standards. In this context, China with its power advantage is a veto-power in decision-making processes. Secondly, consultation with the GMS countries does not have any legal influence on China as it is not a member of MRC and has not approve the UN Watercourses Convention.

Unlike projects of developing regional infrastructure, the question that whether GMS countries will be beneficial from the China-led hydropower projects has received controversial opinions. Benefitting from the cooperation with China to foster hydropower plants, the GMS countries, however, are paying dear costs for their environment. The fact that China builds a series of dams in the upstream of the Mekong River, with the most recent one Xiaowan Dam (292 m high), raised concerns in the academia about negative impacts on the river. According to the Yale Global, there are 18 dams which are built and planned to build along the Mekong River 4,350 km long ${ }^{42}$. Exploiting the hydropower potential of the Lancang River basin will definitely affects the water volume, electricity, agriculture, fisheries, water transportation and ecological environment of the Lower Mekong region, especially the countries of Lao PDR, Thailand, Cambodia and

41 Kayo Onishi, 2013.

42 Michael Richardson, "Dams in China Turn the Mekong Into a River of Discord", Yale Global, June 7, 2009. 
Vietnam. Most importantly, it might transform the structure of coastal villages, and disrupt the lives of local residents who earned their livings from the river. Under the impacts of climate change and changes in the Mekong flows, deltas of downstream countries such as the Cuu Long Delta of Vietnam may face the risk of dehydration and desertification. The author Osborne presents his idea that in the dry season, the Chinese dams hold $40 \%$ water of the whole Mekong River, and hence downstream countries (including Vietnam and Cambodia) will suffer the most of "water security" problems ${ }^{43}$. Besides changes of water flows, unpredictable volume of water use in the upstream region can cause more intense floods and drying for downstream countries.

For example, if the upstream dams release previously held water along with the natural flood, it will create an "artificial flood" wreaking more entailed havocs. The Chinese dams, together with water reservoirs of Thailand, Lao PDR and Cambodia will slow down natural speed of the river's flow, sediment a large amount of silt in the reservoirs, change the water dynamic causing erosion in the downstream area. This also affects the water nutrition and breeding circle of fishes, as well as livelihood of the coastal people. Meanwhile, in the Cuu Long Delta of Vietnam, the local residents still expect annual floods (also called flooding seasons) for fishing, field cleaning and collecting sediment. Only in provinces in the border area of Cambodia and Vietnam, for example, the flooding season every year brings to people here around US\$220 million of incomes ${ }^{44}$.

As such, Mekong River is the "lifeblood" providing most of the food for the downstream countries. A research of Stimson Center shows that operation of the Chinese hydropower dams has changed the river's water flow and impeded the flows of fertile silt which is necessary for maintaining soil productivity, nourishing fishes and preventing sea-water invasion in the Cuu Long Delta. It is estimated that if the sea level rises one meter, the two biggest granaries of Vietnam (Red River Delta and Cuu Long Delta) will be submerged in water of $5,000 \mathrm{~km}^{2}$ and $20,000 \mathrm{~km}^{2}$. This means Vietnam will face the risk of losing 5 million tons of rice each year and hence not producing enough rice for export. The trade-off between hydropower and environment issues creates a serious problem for all countries sharing the Mekong River. Solving the environment issues and aiming to a more sustainable future requires sacrifice of short-term economic benefits by controlling the hydropower boom. Water management in the Mekong River has showed us a typical example of the "collective action" problem and the role of hegemony, in which (i) environmental impacts of the change of water flow become intra-national and serious (in the context of the global climate change); (ii) a cooperation is necessary and important; and (iii) the hegemony, regarding

43 Milton Osborne, River At Risk: The Mekong and the Water Politics of China and Southeast Asia, Lowy Institute Paper 2, The Lowy Institute for International Policy, Sydney, 2004.

44 Interview of the author with Vietnamese scholars in 2011, 2012. 
its power and location advantage, has refused to provide public goods and to participate in cooperative mechanisms.

\section{Conclusion: bringing leadership back in}

This paper examines the role China in the Greater Mekong Sub-region, focusing on efforts to develop transport system (infrastructure) and hydropower dams. The two case studies present two quite different results in terms of Chinese leadership performances. In infrastructure development projects, the Chinese plans to develop regional transport system by building NSEC and the regional railway network received support and proactive participation from GMS countries. A regional traffic network has been built up in which China plays the most important driving force. However, the projects of hydropower bring ambivalent results. This ambivalence presents in the fact the GMS countries accept the Chinese cooperation, at the same time express their concerns about impacts of the Chinese hydropower plans on their national environment (in terms of ecology and economics). Joining to build hydropower dams with China, GMS countries both get benefits and pay costs. To downstream countries such as Cambodia and Vietnam, this is not only the environmental cost but also influences on their agricultural production.

Some indicators reveal that China's geographic position and economical rise allow the Middle Kingdom to be a "system maker" in the region. Together with Japan, China plays an important role in creating various hubs connecting regional transportation, hence fostering investment and trade. China's possible leading role in promoting economic development is an important determinant of the common prosperity of countries in the region. Model of sharing leadership is an appropriate explanation for the Chinese promotion. In contrast, China is facing responses from GMS countries in the hydropower projects since it has no balance between Beijing's national interests and demand for regional development of the countries. The current situation with the increasing involvement of the US and Japan in the fields of water management and environment, which China refused to provide an inclusive leadership, shows that it is changing unfavorably to China. The US and Japan have conducted different policies in GMS including enhancing public or private goods, and establishing a shared vision with GMS countries. This hints the possibility of becoming regional leaders of the countries in terms of managing the Mekong River sustainably. In this context, China may face leadership rivalry containing more uncertainty and risks.

As such, which message could be leant from the findings within debates about the role of China as a rising power in the forming order of the region and the world? Regarding lesser states' perspective (both in GMS and the SEA), the prerequisite to keep accepting China as a new "system maker" is that Beijing undertakes more international responsibility. The main driving force prompts other countries to voluntarily adjust their policies to the Chinese one is its regional 
or global responsibility. Indeed, the emergence and responsibility are two aspects that complement each other. Emerging in some fields, but not being able to take responsibility, can make it neither a full emergence nor a great power. The Chinese policy in GMS has shown that the emergence of capabilities created opportunities for China to shape the regional order and take advantage of it. Nevertheless, only focusing on the role of privilege taker may lead to a contrary result impacting inversely on the Chinese leading position. Efforts to share interests with close partners cannot offset response from the structure when the issue influences regional countries, and China — as an expected leader — turns its back on that responsibility. This proves two side effects of the globalization to rising powers like China, when it creates opportunities for powers to become a system influencer but at the same time will increasingly constrain its ability to continue to enjoy the special privileges to which it has become accustomed.

From the Chinese view, becoming a power responsible for providing public goods or private goods in many cases is costly which can be a "trap" forcing China to contribute more, however. Therefore, from the most realistic view, China in the next few years will be a mix of elements of responsible leadership which are selective in different situations. "How to choose" and "in which field" amid the country's political status are questions that require lucid decisions of Chinese elites. During the rising time of a country, when it reaches a particular level, a part or even most of the population become misconceive about their power. Hence, there will be people asking for the hegemonic position with ambitions over its real capabilities. Meanwhile, other groups may support an insular nationalism highlighting their national interests above all. There can be some other ideas or approaches reconsidering the role of China as a hegemon and other countries as "China's tributaries." In this context, choices of the elites play the key role. If the elite group support the mass public or take advantage of their mood serving for their own interests, the country will fall into a tragic plight. In contrast, if the elites remain their perspicaciousness and mobilize judicious people to go against the opposite ones, the country can rise peacefully and fulfill its mission of a great power.

Submitted November 30, 2013 Accepted February 19, 2014

\footnotetext{
Abstract

Utilizing China's leadership projects in the Great Mekong Sub-Region (GMS) as a case study, this paper aims to investigate whether China qualifies as an international leader. This work argues that its geographic position and economic rise allow China to be a "system maker and privilege taker," which is a dual role forming in economic-political relations in the GMS in the last ten years. China is among major driving forces to set up an economic zone in GMS. Growing Chinese regional power is intimately related to the creation of various hubs connecting regional
} 
transportation, communication and energy systems that foster the economic development of this region. However, China also proves dark sides of rising powers which take advantage of their privileges to gain benefits. As a "system maker" with its own position and capability, China has notably benefited from building hydropower systems. More importantly, while China is pursuing its benefits and privileges, its hydropower projects have caused some negative effects for the ecosystem in the region. The inflation of dam constructions in both China and GMS countries is raising concerns about using natural resources of the Mekong River. Our concluding part addresses the pressing need to start a serious discussion on the balance between national interests and regional solidarity within the formulation of Chinese foreign policy in GMS.

Keywords: China's rise; Great Mekong Sub-Region; system maker, privilege taker.

\section{Resumo}

Utilizando os projetos de liderança da China na Sub-região do Grande Mekong (GMS) como estudo de caso, este artigo almeja investigar se a China se qualifica como um líder internacional. Este trabalho argumenta que sua posição geográfica e ascensão econômica permitem que a China seja um "criador do sistema e aproveitador de privilégios", que é um duplo papel, formando relações econômico-políticas na GMS nos últimos dez anos. A China está entre as maiores forças impulsoras a estabelecer uma zona econômica na GMS. A crescente potência regional chinesa está intimamente relacionada com a criação de vários centros que conectam sistemas regionais de transporte, comunicação e energia que fomentam o desenvolvimento econômico dessa região. Entretanto, a China também passa pelo lado sombrio das potências em ascensão que se aproveitam de seus privilégios para se beneficiar. Como uma "criadora do sistema" com sua própria posição e capacidade, a China se beneficiou visivelmente de ter construído sistemas de energia hidrelétrica. Mais importante, enquanto a China segue atrás de seus benefícios e privilégios, seus projetos de hidrelétricas têm causado alguns efeitos negativos para o ecossistema na região. O crescimento das construções de represas tanto na China quanto na GMS está causando preocupações sobre o uso de recursos naturais do rio Mekong. Nossa conclusão aborda a necessidade premente de iniciar uma discussão séria sobre o equilíbrio entre interesses nacionais e solidariedade regional dentro da formulação da política externa chinesa na GMS.

Palavras-chave: ascensão da China; Sub-região do Grande Mekong; criador do sistema, aproveitador de privilégios. 